\title{
Shallow genetic divergence indicates a Congo-Nile riverine connection for the softshell turtle Trionyx triunguis
}

\author{
Muge Gidis • Phillip Q. Spinks • Ethem Çevik • \\ Yakup Kaska $\cdot$ H. Bradley Shaffer
}

Received: 23 July 2010/ Accepted: 25 October 2010/Published online: 16 November 2010

(C) The Author(s) 2010. This article is published with open access at Springerlink.com

\begin{abstract}
We sequenced 20 new, field-collected individuals for up to seven genes to explore the phylogeography and conservation genetics of the threatened Nile softshell turtle Trionyx triunguis, including the first known-locality specimen from sub-Saharan Africa. Samples from Cameroon (West Africa), the Mediterranean and Nile River differed by at most a single nucleotide per gene, indicating the potential for a recent connection between these currently disjunct populations via the Nile-Congo River systems. Recently reported mitochondrial diversity between Mediterranean and "sub-Saharan" samples of the Nile softshell indicate that significant divergence exists across the species' range, but that variation cannot be fully incorporated into our analysis since those samples lack specific locality data.
\end{abstract}

Electronic supplementary material The online version of this article (doi:10.1007/s10592-010-0160-2) contains supplementary material, which is available to authorized users.

\section{Gidis}

Gediz Vocational School, Dumlupinar University, Gediz,

Kutahya 43600, Turkey

P. Q. Spinks · H. B. Shaffer $(\square)$

Department of Evolution and Ecology and Center for Population Biology, University of California, Davis, Davis, CA 95616, USA e-mail: hbshaffer@ucdavis.edu

E. Çevik

Department of Biology, Faculty of Sciences, Ege University, Izmir 35100, Turkey

Y. Kaska

Department of Biology, Faculty of Arts and Sciences,

Pamukkale University, Denizli 20100, Turkey
Keywords Trionyx triunguis · Congo River · Nile River · Kükürtlü Lake · Africa · Mediterranean Sea · Cameroon · African phylogeography

\section{Introduction}

Species with widely disjunct distributions offer an interesting puzzle to systematists and biogeographers. On the one hand, disjunctions often imply a corresponding deep split within the species, including the potential for cryptic speciation. On the other, the absence of a species over some of its range may be a function of a recent range contraction driven by human-mediated or natural habitat changes with little or no associated genetic divergence. When a species is also a high conservation priority, distinguishing between these two alternatives constitutes an important element of effective conservation planning.

The Nile softshell turtle Trionyx triunguis is an aquatic species inhabiting freshwater lakes and rivers, but it is also commonly encountered in marine habitats ranging from estuaries to the depths of 100 meters in the Mediterranean Sea (Kasparek 2001). The current distribution of T. triunguis is highly disjunct (Fig. 1) and is composed of three regions: 1) coastal west Africa from Namibia through northern Senegal, including scattered inland localities from the Congo and Niger Rivers, 2) east-central Africa from Tanzania through the Nile River drainage, including the eastern Mediterranean, and 3) east Africa in coastal flowing rivers in Somalia.

Most research on this species comes from the northern Mediterranean region (Gidis and Kaska 2004; Gramentz 1994; Kasparek and Kinzelbach 1991; Taşkavak 2003) where it has been an important conservation target. Mediterranean populations from Israel, Lebanon, Syria and 
Fig. 1 Map of Africa showing the major rivers and distribution of Trionyx triunguis (dark circles from http://emys.geo.orst.edu/). Genetic samples indicated by circles + dots

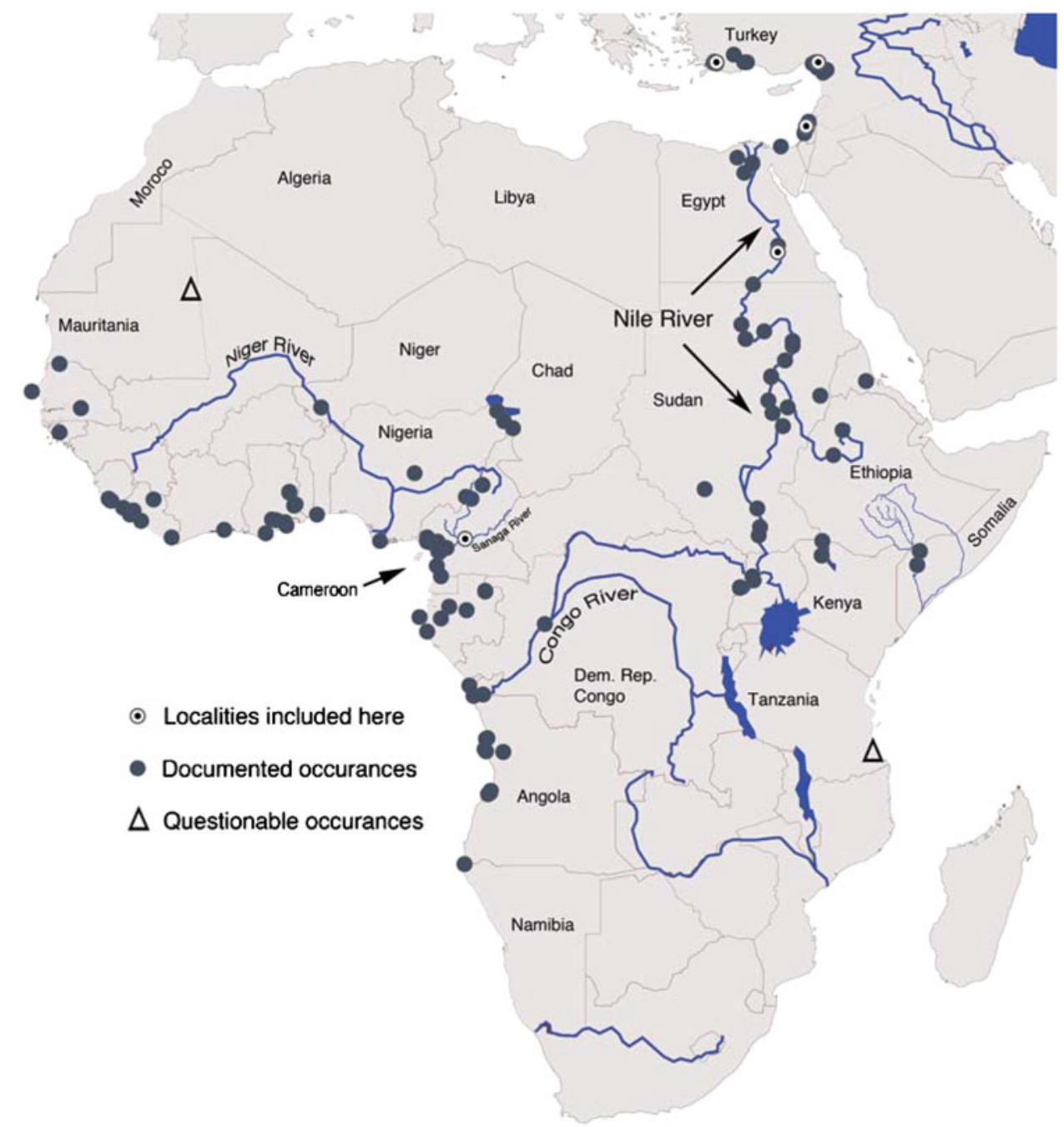

Turkey were listed as Critically Endangered in the 1996 and 2002 IUCN Red Data Book (Kasparek 2001), on Appendix II of the Convention on the Conservation of European Wildlife and Natural Habitats, and on Appendix III of CITES (Kasparek 2001). Although many workers still consider the Mediterranean populations to be threatened (e.g. Cox et al. 2006), T. triunguis was recently delisted (IUCN 2010). Critical to this decision is the evaluation of $T$. triunguis as a single undifferentiated species across the Mediterranean and Africa.

Although some work has been conducted on the distribution and reproductive ecology of this species (Atatür 1979; Gidis and Kaska 2004; Gramentz 1994; Kasparek and Kinzelbach 1991; Kasparek 1999), genetic studies of T. triunguis have been limited to mitochondrial DNA (mtDNA) analyses, primarily of Mediterranean populations. Rosner (2007) assessed mtDNA cyt $b$ diversity among 18 turtles, and Güçlü et al. (2009) analyzed two mtDNA gene regions (cyt $b$ and ND4) for 22 turtles from
Israel and Turkey, and found a few singleton nucleotide substitutions, none of which were phylogenetically or geographically informative. However, Güçlü et al. (2009) also reported that four $T$. triunguis samples from unknown "sub-Saharan Africa" localities were approximately $1.5 \%$ divergent in mtDNA sequence from the Mediterranean samples, suggesting that some phylogeographically informative variation exists within the species.

We generated sequence data from two mtDNA and five nuclear DNA (nuDNA) markers to assess differentiation between the two major disjunct components of the species in coastal west Africa and the eastern Mediterranean/Nile River. Field-verified tissue samples for genetic analyses of T. triunguis from sub-Saharan Africa are extremely rare, but we located and sequenced one individual with reliable locality data collected in Cameroon and now housed at the San Diego Zoo, California USA. Although our sub-Saharan sampling is extremely limited, it provides the first verified 
locality from west Africa for this widely disjunct species (Fig. 1).

\section{Materials and methods}

Taxon and data sampling

We sequenced 19 new $T$. triunguis specimens collected by the senior author in Turkey, including 18 from Lake Kükürtlü at the far western edge of the species range and one from Mersin in eastern Turkey, as well as one Cameroon specimen from the Sanaga River (See Appendix in Supplementary material). Given the low levels of mtDNA variation previously detected, we attempted to sequence all of our samples for the mitochondrial control region (CR) to assess variation from a potentially more variable marker (Starkey et al. 2003). We also sequenced a subset of seven individuals, including the Cameroon, Mersin, and five Lake Kükürtlü specimens, for cyt $b$ to compare with previously published analyses. To gain a nuclear gene perspective, we also sequenced five nuclear genes for four Turkish specimens (one from Mersin and three Lake Kükürtlü) and the Cameroon sample (See Appendix in Supplementary material). We included all previously generated $T$. triunguis cyt $b$ sequences that we could locate, including the three available GenBank cyt $b$ sequences from Güçlü et al. (2009), and three from Lake Nassar, Egypt (GenBank accession\# AB477345, plus two extracted from Amer and Kumazawa (2009)). We also included 17 cyt $b$ sequences from Lake Alexander, Israel and Lake Kükürtlü, Turkey (extracted from Rosner 2007), and two GenBank sequences lacking locality data (Fig. 2).

Molecular methods

DNA was extracted with a standard salt extraction protocol, and the cyt $b$ and CR sequences were generated using primers and PCR conditions from Spinks et al. (2004) and Starkey et al. (2003), respectively. Our nuDNA markers included the Aryl hydrocarbon receptor (AHR, Townsend et al. 2008); the brain derived neurotrophic factor (BDNF, Noonan and Chippindale 2006), the bone morphogenetic protein-2 (BMP2, Townsend et al. 2008), the fingerprint protein 35 (R35, Fujita et al. 2004), and TB01, an anonymous nuclear marker (Thomson et al. 2008). Several of these markers amplify well across turtles, including the softshell Dogania subplana (Spinks et al. 2010a, b). PCR conditions for the nuclear markers were: $95^{\circ} \mathrm{C}$ denature for $2 \mathrm{~min}, 54-65^{\circ} \mathrm{C}$ anneal for $45 \mathrm{~s}$ and 72 extension for $1 \mathrm{~min}$ for 38 cycles. All reactions were run using negative controls, PCR products were cleaned using exo/sap and sequenced in both directions at the UC Davis Division of Biological Sciences sequencing facility (http://dnaseq.ucdavis.com/).

Phylogenetic analyses

All sequences were edited and aligned using MUSCLE (Edgar 2004). We checked for pseudogenes by examining all mtDNA chromatograms for double peaks and confirming that the protein-coding genes (all but CR, R35 and TB01)
Fig. 2 Maximum likelihood (a), and Majority rule consensus tree from the posterior distribution of trees from the Bayesian analysis (b) of cyt $b$ data from 11 Trionyx triunguis plus one Chitra vandijki outgroup (22 additional sequences were identical to ingroup sequences and were excluded from phylogenetic analyses). Terminal labels are locality followed by the GenBank accession \# except for Lake Nassar, Egypt \#1, and \#3 which were transcribed from Amer and Kumazawa (2009). ML bootstrap support values (a) and Bayesian posterior probabilities (b) shown above branches. Outgroup branches not drawn to scale

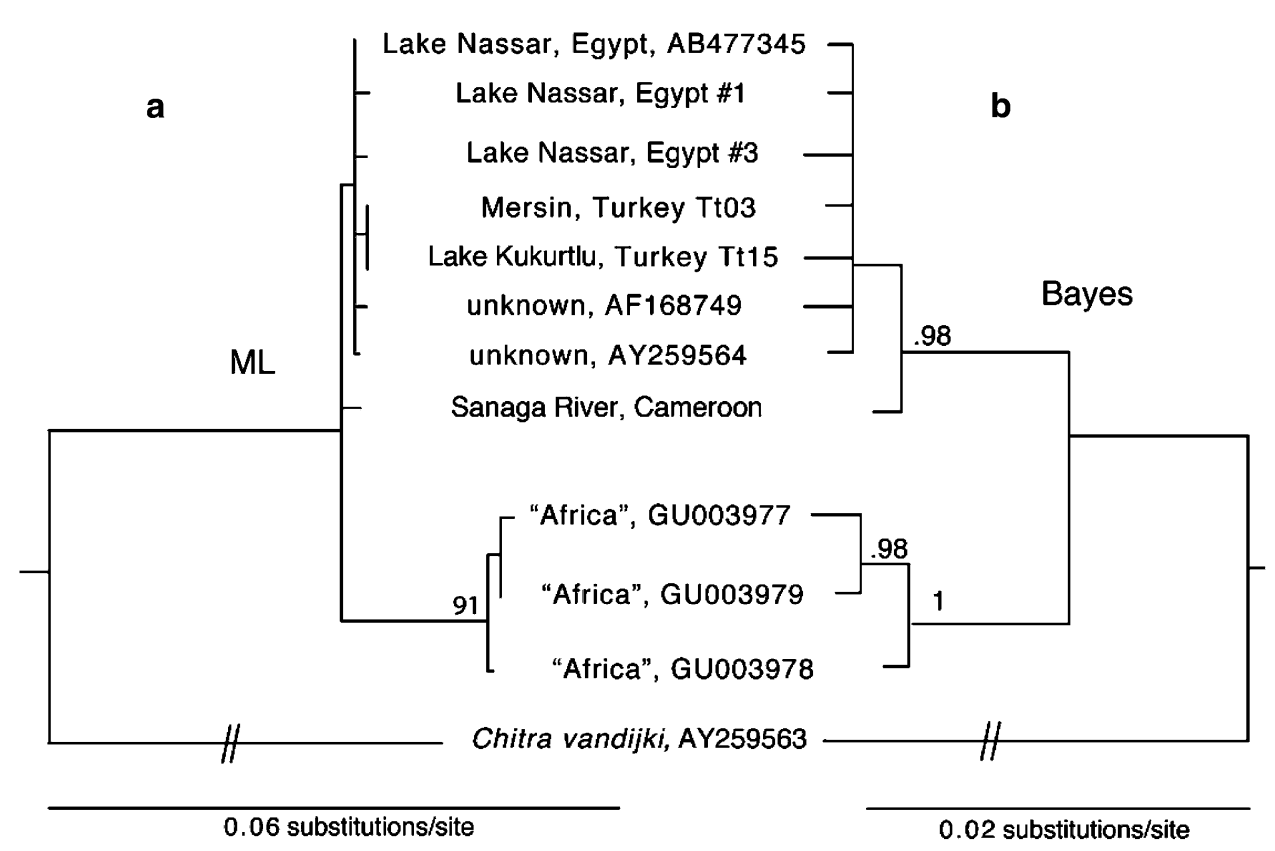


translated using Geneious 4.8.5. Cyt $b$ gene trees were reconstructed using Maximum likelihood (ML) and Bayesian inference (BI). The genera Chitra and Pelochelys form the sister clade to Trionyx (Engstrom et al. 2004), therefore we used Chitra vandijki as the outgroup. ML analyses were performed using PAUP* 4.0b10 (Swofford 1998) with ten random stepwise heuristic searches and tree bisectionreconnection (TBR) branch swapping. Models of molecular evolution for parameter estimation were selected using the DT-Modsel software (Minin et al. 2003) with parameters values estimated using PAUP* $4.0 \mathrm{~b} 10$ and statistical support estimated with 1000 ML bootstrap pseudoreplicates. BI analyses were performed using MrBayes V3.1.1 (Ronquist and Huelsenbeck 2003) with two replicates and four chains for $1 \times 107$ generations. Chains were sampled every 1000 generations, and stationarity was determined as the point when the potential scale reduction factor (PSRF) equaled 1 and when the $\log$ likelihood $(-\ln \mathrm{L})$ scores plotted against generation time reached a stationary value.

\section{Results}

\section{Mitochondrial DNA}

Our control region data set contained up to 643 base pairs (bp) for 19 individuals (one from Egypt-AB477345, one from Mersin, and 17 from Lake Kükürtlü), all of which were identical. Although we tried multiple times, we were unsuccessful in amplifying and sequencing CR from the remaining Lake Kükürtlü and the Cameroon specimen. As these sequences were identical, we did not perform phylogenetic analyses on these data.

Aligning our cyt $b$ sequences with those from Rosner (2007) was problematic. The alignment of Rosner (2007) contained several putative insertions/deletions (indels) and heterozygous positions resulting in nonsense mutations when translated (see TreeBase Accession \#10931). We excluded seven problematic nucleotide positions, resulting in a data set of up to 775 nucleotides for 34 individuals including the Chitra vandijki outgroup, 18 extracted from Rosner (2007), two extracted from Amer and Kumazawa (2009), seven from GenBank, and seven new sequences from the current study, TreeBase Accession \#10931). However, all of our cyt $b$ sequences were identical to the Mediterranean sequence reported by Güçlü et al. (2009) except for the Cameroon sequence which differed by a single substitution (TreeBase Accession \#10931). Therefore, we excluded most of the identical sequences and performed phylogenetic analyses on 12 sequences only (11 T. triunguis plus the outgroup). Maximum likelihood analyses of the cyt $b$ data recovered two equally likely trees. Under ML and BI, the sub-Saharan Africa GenBank samples of unknown provenance from Güçlü et al. (2009) formed a monophyletic group with strong support (Fig. 2a, b). BI analysis recovered the Cameroon and Mediterranean samples as monophyletic with strong support (Bayesian posterior probability $=0.98$, Fig. $2 b$ ), whereas under ML there was no evidence for the monophyly of either Mediterranean samples with or without the Cameroon specimen (Fig. 2a).

\section{Nuclear DNA}

Our nuDNA data set consisted of $3469 \mathrm{bp}$ for five individuals including $555 \mathrm{bp}$ of AHR, $672 \mathrm{bp}$ of BDNF, $648 \mathrm{bp}$ of BMP2, 921 bp of R35, and 673 bp of TB1 (for additional information on these genes, see Barley et al. 2010). These data were mostly invariant (four variable sites, none of which were parsimony informative), and we did not pursue further phylogenetic analyses. The Cameroon sample contained two autapomorphies; one in AHR and one in R35, while two sites in R35 were variable among the Turkish samples only (TreeBase Accession \#10931).

\section{Discussion}

Previous work on other softshell turtles has generally indicated moderate to high levels of mtDNA genetic divergence (up to about $8 \%$ ) within wide-ranging species (Engstrom et al. 2002, Weisrock and Janzen 2000, McGaugh et al. 2008), significant nuDNA divergence among closely related species, and slight nuDNA variation within wide-ranging species (McGaugh et al. 2008). Given the disjunct distribution of $T$. triunguis and the moderate mtDNA divergence previously reported by Güçlü et al. (2009), we expected that moderate to high differentiation would exist across our samples. However, we found no mtDNA variation among Mediterranean turtles from Turkey and Israel, and the Cameroon and one of the three Egyptian sequences (\#3) differed from each other and the Mediterranean samples by only a single, unique cyt $b$ substitution. We found similarly low levels of genetic divergence across five nuclear gene sequences, even though some of these markers are generally informative within or among closely related species (Engstrom et al. 2002, McGaugh et al. 2008, Spinks and Shaffer 2009, Spinks et al. 2010). Thus, $4244 \mathrm{bp}$ of nuclear and mitochondrial data indicate little divergence between the Mediterranean and our west African Cameroon sample. There is the possibility that the two single-nucleotide substitutions that we detected in AHR and R35 constitute consistent singlenucleotide differences, implying a roughly $0.05 \%$ sequence divergence between these samples. However, our current working hypothesis is that they are essentially 
undifferentiated and should tentatively be treated as a single conservation unit.

This exceedingly low level of genetic divergence suggests that either $T$. triunguis expanded recently to its current distribution or that relatively recent gene flow links Mediterranean, Nile River, and west African populations. Trionyx triunguis commonly enters open salt water, but the lack of any documented specimens from North Africa (Fig. 1) suggests that oceanic dispersal across this $6000 \mathrm{~km}$ hiatus is unlikely. A more plausible explanation is dispersal across central Africa via the Nile-Congo Rivers. These rivers have a broad region of near-overlap along the Democratic Republic of Congo/Tanzania-Uganda-Sudan borders, and other aquatic organisms indicate strong biogeographic connections between the Nile and Congo (Salzburger et al. 2005). Trionyx triunguis has been collected in both drainages suggesting a relatively direct potential link between coastal West African and Nile/ Mediterranean populations (Fig. 1). Under this hypothesis, the large distributional gap in central Africa could be due to a recent range contraction (perhaps associated with a recent lack of appropriate habitat in the region) or an artifact of the sparse scientific collecting across much of central Africa.

Phylogeographic research is fundamental for understanding the distributions of species and to delimit targets of intraspecific conservation. Unfortunately, for many taxa, thorough phylogeographic analyses are hindered by a lack of samples with reliable locality data. Trionyx triunguis exemplifies this problem. mtDNA variation was documented by Güçlü et al. (2009), but the geographic distribution of this variation is uncertain. Given that our Cameroon sample was virtually identical genetically to eastern Mediterranean/Nile individuals, we hypothesize that the divergent mtDNA sequences from Güçlü et al. (2009) might have come from the Somali isolate, or perhaps from more northerly west African populations in the Niger River drainage. Future work on this species should include broader sampling from coastal West African and Somali populations, and should include additional data from the nuclear genome.

Acknowledgments Dwight Lawson collected the Cameroon turtle, and the San Diego Zoo provided a blood sample for our work, Permits were granted from the Republic of Turkey Ministry of Environment and Forestry. This work was supported by a grant from The Scientific and Technological Research Council of Turkey (TUBITAK), NSF grant DEB 0817042 and the UC Davis Agricultural Experiment Station. We thank Bob Thomson and members of the Shaffer lab for discussion. This study is a part of Muge Gidis's Ph.D. thesis.

Open Access This article is distributed under the terms of the Creative Commons Attribution Noncommercial License which permits any noncommercial use, distribution, and reproduction in any medium, provided the original author(s) and source are credited.

\section{References}

Amer SAM, Kumazawa Y (2009) Complete sequence of the mitochondrial genome of the endangered Nile soft-shelled turtle Trionyx triunguis. Egypt J Exp Biol (Zool) 5:43-50

Atatür MK (1979) Investigations on the morphology and osteology, biotope and distribution in Anatolia of Trionyx triunguis (Reptilia, Testudines) with some observations on its biology, vol 18. Ege University Faculty of Science Monographs, Izmir, Turkey, pp 1-75

Barley AJ, Spinks PQ, Thomson RC, Shaffer HB (2010) Fourteen nuclear genes provide phylogenetic resolution for difficult nodes in the turtle tree of life. Mol Phylogenet Evol 55:1189-1194

Cox N, Chanson J, Stuart S (2006) The status and distribution of reptiles and amphibians of the Mediterranean Basin. IUCN, Gland, Switzerland and Cambridge, UK

Edgar RC (2004) MUSCLE: multiple sequence alignment with high accuracy and high throughput. Nucl Acids Res 32:1792-1797

Engstrom TN, Shaffer HB, McCord WP (2002) Phylogenetic diversity of endangered and critically endangered southeast Asian softshell turtles (Trionychidae: Chitra). Biol Conserv 104:173-179

Engstrom TN, Shaffer HB, McCord WP (2004) Multiple data sets, high homoplasy, and the phylogeny of softshell turtles (Testudines: Trionychidae). Syst Biol 53:693-710

Fujita MF, Engstrom TN, Starkey DE, Shaffer HB (2004) Turtle phylogeny: insights from a novel nuclear intron. Mol Phylogenet Evol 31:1031-1040

Gidis M, Kaska Y (2004) Population size, reproductive ecology and heavy metals in eggshells of the Nile Soft-shell turtle (Trionyx triunguis) around thermal lake Kükürtlü (Sulphurous), MuglaTurkey. Fresen Environ Bull 13:405-412

Gramentz D (1994) Zur Thermoregulation von T. triunguis am Kükürtlü Gölü in West-Anatolien. Salamandra 30:143-154

Güçlü Ö, Ülger C, Türkozan O, Gemmel R, Reımann M, Levy Y, Ergene S, Uçar A, Aymak C (2009) First assessment of mitochondrial DNA diversity in the endangered Nile Softshell Turtle, Trionyx triunguis in the Mediterranean. Chelonian Conserv Biol 8:222-226

IUCN (2010) IUCN Red List of Threatened Species Version 2010.1. http://www.iucnredlist.org. Accessed 12 April 2010

Kasparek M (1999) An assessment on the status of the Nile softshelled turtle (T. triunguis) in Turkey with recommendations for conservation. Testudo 5:40-50

Kasparek M (2001) Priorities for the conservation of the Nile softshelled turtle, Trionyx triunguis in the Mediterranean. Testudo (The Journal of the British Chelonia Group) 5:49-59

Kasparek M, Kinzelbach R (1991) Distribution and bionomics of the Nile soft-shelled turtle, T. triunguis, in the Eastern Mediterranean. Zeitschrift für angewandte Zoologie 78:137-159

McGaugh SE, Eckerman CM, Janzen FJ (2008) Molecular phylogeography of Apalone spinifera (Reptilia, Trionychidae). Zoologica Scripta 17:289-304

Minin V, Abdo Z, Joyce P et al (2003) Performance-based selection of likelihood models for phylogeny estimation. Syst Biol 52:674-683

Noonan BP, Chippindale PT (2006) Vicariant origin of Malagasy reptiles supports late cretaceous Antarctic land bridge. Am Nat 168:730-741

Ronquist F, Huelsenbeck JP (2003) MRBAYES 3: Bayesian phylogenetic inference under mixed models. Bioinformatics 19:15721574

Rosner O (2007) Aspects of the ecology of the Nile softshell turtle (Trionyx triunguis) in the Alexander River. Dissertation, University of Haife 
Salzburger W, Mack T, Verheyen E, Meyer A (2005) Out of Tanganyika: genesis, explosive speciation, key-innovations and phylogeography of the haplochromine cichlid fishes. BMC Evol Biol 2005:5-17

Spinks PQ, Shaffer HB (2009) Conflicting mitochondrial and nuclear phylogenies for the widely disjunct Emys (Testudines: Emydidae) Species Complex, and what they tell us about biogeography and hybridization. Syst Biol 58:1-20

Spinks PQ, Shaffer HB, Iverson JB, McCord WP (2004) Phylogenetic hypotheses for the turtle family Geoemydidae. Mol Phylogenet Evol 32:164-182

Spinks PQ, Barley AJ, Thomson RC, Shaffer HB (2010) Testing avian, squamate, and mammalian nuclear markers for cross amplification in turtles. Cons Genet Resour. doi:10.1007/s12686010-9184-7

Spinks PQ, Thomson RC, Shaffer HB (2010b) Nuclear gene phylogeography reveals the historical legacy of an ancient inland sea on lineages of the western pond turtle, Emys marmorata in California. Mol Ecol 19:542-556

Starkey DE, Shaffer HB, Burke RR et al (2003) Molecular systematics, phylogeography, and the effects of Pleistocene glaciation in the painted turtle (Chrysemys picta) complex. Evolution 57:119-128

Swofford DL (1998) PAUP*: Phylogenetic analysis using parsimony (*and other methods). Sinauer Associates, Sunderland

Taşkavak E (2003) Nil Yumuşak Kabuklu Kaplumbağası'nın, Trionyx triunguis (Forskal, 1775), Kıyılarımızdaki son durumu ve türü korumaya yönelik alternatif bir tedbir. Ankara Türk Sucul Yaşam Dergisi 1:62-68

Thomson RC, Shedlock AM, Edwards SV, Shaffer HB (2008) Developing markers for multilocus phylogenetics in non-model organisms: a test case with turtles. Mol Phylogenet Evol 49:514-525

Townsend TM, Alegre RE, Kelley ST, Weins JJ, Reeder TW (2008) Rapid development of multiple nuclear loci for phylogenetic analysis using genomic resources: an example from squamate reptiles. Mol Phylogenet Evol 47:129-142

Weisrock DW, Janzen FJ (2000) Comparative molecular phylogeography of North American softshell turtles (Apalone): implications for regional and wide-scale historical evolutionary forces. Mol Phylogenet Evol 14:152-164 